\title{
The Concept of Human Capital - the Need for an Interdisciplinary Synthesis
}

\author{
Valerii S. Efimova, Alla V. Lapteva ${ }^{a}$ \\ and Evgenia I. Mikhailova ${ }^{\mathrm{b} *}$ \\ ${ }^{a}$ Siberian Federal University \\ 79 Svobodny, Krasnoyarsk, 660041, Russia \\ ${ }^{b}$ North-Eastern Federal University \\ 58 Belinsky, Yakutsk, 677027, Russia
}

Received 20.07.2016, received in revised form 18.09.2016, accepted 29.10.2016

The article presents a review of theoretical and empirical studies of human capital, which has showed inadequacy of reduced representations about man, his activity and the possibility to implement it. Based on the performed critical analysis, the article substantiates the necessity to develop a systemic model of human capital, which is to unite the classical concepts of human capital and its components (education and competencies, health, demographic potential) with advanced concepts, including personal qualities of a person, activity, identity; the features of not only individuals but also collectives and groups; the concept of social capital; representations about the conditions, media and institutions that provide human development and capitalization; ideas about subjects of human capitalization; representations of the negative processes leading to 'dissipation' of human resources.

Two groups of categories are offered on the basis of the philosophical and methodological analysis. They are material - processes - conditions and subjects - interests/positions - activity, allowing us to carry out the system assembly of the ideas about human capital.

With respect to the applied empirical research, the article discusses the most important focus of human capital studies; significant components (characteristics) of human capital; the methods of research (fixation, evaluation) of the most important characteristics of human capital.

Keywords: human capital, system ideas, system of categories, research methods.

DOI: 10.17516/1997-1370-2016-9-11-2664-2680.

Research area: economics.

\section{Introduction}

Currently, the human capital is considered to be the most important factor of the socioeconomic development of countries, regions and cities. The economic activity of man, his competence, education, physical and mental health has a significant influence on the dynamics of the economy. Investments in people, namely in education, health, quality of life, are found the most important part to manage the development of social systems (city, region, country).

It is necessary to create a theory of human capital, which would take into account the modern ideas about the productive capabilities of

(C) Siberian Federal University. All rights reserved

* Corresponding author E-mail address: efimov.val@gmail.com; avlapteva@yandex.ru; rector@s-vfu.ru 
man, the characteristics and conditions of their implementation as a scientific basis for human development, investment in human capital, the unfolding of new social and human practices aimed at human development.

Currently, the economic approach dominates in the research of human capital. This approach regards man as a 'production function' and studies the costs of training skilled workers and increasing their productivity in the logic of the growth in labor productivity and reducing unproductive costs. The return on 'investment in people' in business organizations is well described in these studies, and recommendations on it are widely used in the corporate sector (Belkin et al, 2012; Mil'ner, 2008). Restrictions in the concepts of human capital as a factor of production were discovered while transferring this approach to complex social and economic systems such as countries, regions and cities. The economic approach to the study of man hardly takes into account the specificity of collective activity and the synergistic effects arising from this; beyond the scope of this approach are cultural, social and infrastructural features of complexly organized systems that determine the restrictions or the possibilities of 'return' of man and human capitalization.

The discovered limitations and contradictions of different models, methods and tools of human capital research necessitates the development of a systemic model of human capital and the necessary methods to study it in the framework of such a model. To this end, it is important to enter the philosophical and methodological level of the analysis, to define groups of basic categories, which allow 'holding' the complex phenomena of human activity and human capitalization. The task of the article is to hold a methodological analysis and present the concept of human capital for an integrated multidisciplinary study of human activity in complex socio-economic systems (country, region, city).

\section{Studies of human capital - an overview ${ }^{1}$}

The basic concepts of human capital were formed by the classics of economic theory. W. Petty wrote about the population and the labor force as a source of national wealth in the $17^{\text {th }}$ century. A. Smith in the $18^{\text {th }}$ century saw the skill and knowledge of people as a prerequisite for economic relations and raised the question of the relevance and cost recovery for the training of workers ${ }^{2}$. K. Marx, J.S. Mill, L. Walras built the theories and models, in which the productive qualities of workers were a necessary condition for the economic growth. The modern understanding of human capital was formed in the 60 -ies of the $20^{\text {th }}$ century, based on the works of the American scientists, Nobel laureates T. Schultz and G. Becker, as well as the representatives of the Chicago school B. Weisbrod, L. Thurow and J. Mincer, who substantiated the expediency of investment in man. The return on 'investment in man' on the level of macroeconomics was studied by P. Romer, R. Lucas, G. Kendrick. T. Schultz and E.F. Denison proposed macro-economic models, linking investment in education with the growth of national income. In the second half of the $20^{\text {th }}$ century, there was a special area of research such as economic demography; the attention of researchers was focused on the health of population as an object of investment and a condition of the economic growth. T. Schultz (Schultz, 1981) introduced the concept of the economy of quality of the population'.

Currently, the role of quality of labor as a factor of economic growth and development of socio-economic systems is well recognized. Since 1990-ies the problems of human capital has taken a leading position in economic research; while the accumulation of human capital is considered to be 
not a less important factor in the development of economic systems than savings and investment. There was an understanding of the structure of human capital (Machlup, 1984; Bowen, 1978), consisting of knowledge and competencies, resulting from training and work experience, health, motivation and activity (labor, education, and others). The formal models of human capital were developed (e.g., I.V. Il'inskii (1996) represents human capital as the total of health capital, education capital and culture capital). There were some ideas about 'capitalization' as a process of conversion of human potential into capital itself, about the conditions of the process. At the end of the $20^{\text {th }}$ century and the beginning of the $21^{\text {st }}$ century the shift of emphasis in the understanding of the importance of human capital for the economic growth has occured: not only the higher productivity of skilled and educated workers is important (that was emphasized by the founders of the human capital theory), but also those qualities of man, by means of which he is the source of new ideas and innovations, as well as the features facilitating the perception and dissemination of innovation (R. Lucas, P. Romer and others see the review work of I.V. Soboleva, 2009). An expanded view of the structure of human capital appeared. It included a set of personal qualities, values and attitudes that ultimately determine the performance of human activities; these qualities include not only cognitive, but also emotional, communication and other qualities (Bovenberg, 2008; Handel, 2003).

The world science uses various indicators of human capital, namely, natural and cost indicators (Schultz, 1971), special integral indices; various methods of measurement and evaluation of human capital were developed on the basis of an assessment of incurred costs and investments, on the basis of return on human capital, etc. (see the works that contain reviews and criticism - Kapeliushnikov, 2008;
Soboleva, 2009). However, there is a number of methodological and technical difficulties of measurement and evaluation of human capital, all the existing approaches have certain internal contradictions, the results of applying different methods are weakly consistent. In the Russian science various aspects of measurement and quantification of human capital at different levels (national, regional) are discussed by S. Valentei (1999), A.I. Dobrynin et al. (1999a, 1999b), Iu.N. Ivanov and A.A. Sagradov (2001), I.V. Soboleva (2009), R.I. Kapeliushnikov (2012).

A number of works with a methodological and critical focus discuss accumulated contradictions and problems in the studies of human capital. Thus, based on a review of a wide range of publications, I.V. Soboleva (2009) analyzes the problems and paradoxes of human capital measurement, estimation of its accumulation and its economic impact. I.V. Soboleva also shows a number of more specific problems and paradoxes arising from the application of specific methods of measurement and evaluation of human capital.

In our opinion, moving towards system notions of human capital, overcoming the separation and opposition of human capital and social capital, including ideas about the conditions (institutional and environmental) of human capitalization, is necessary. The interdisciplinary synthesis, which would connect (or put into a single field of review and correlate) economic, demographic, sociological and culturological representations and data about man and his productivity is also necessary. The position of P. Bourdieu (Bourdieu, 2011) is interesting in this respect in the world science. He proposed to consider any limited resource as a capital, which can be accumulated, stored and converted into other types of resources (not only economic, human, social capitals, but also cultural political and symbolic capitals) ${ }^{3}$. 
There has seen a dramatic expansion of human self-realization in recent decades, which is due to the acceleration of the process of technological development, globalization of production, labor and capital markets, increasing the access to information, communication, education, goods and services, increasing transparency, spatial, social and professional mobility, improving the quality and length of life. These processes are seen as a long-term trend and are the basis for the expectations (by the population of most countries and regions) of a further increase of the quality of life, self-realization opportunities (education, personal and professional growth). These expectations have a significant influence on the level of economic and social activity of people. The vision of the future and the 'motivating' attitudes associated with it can be designated as a special component of human capital - 'the capital of perspective'. It is determined by the way people think about the future (of an organization, region, country), influencing the intentions, goals, human activity, which is reflected further in the economic, migration, social and cultural activity of people.

Russian scientists have studied various aspects of human capital. For example, the approaches to the study of the regional human capital are offered by A.I. Dobrynin et al. (1999a), V.A. Shabashev and S.I. Shorokhov (2015), etc .; the human capital of the Russian regions are discussed by N.V. Zubarevich (2016), V.S. Efimov et al. (2015). The quality of life of the population was analyzed by S.A. Aivazian (2003a; 2003b). The health capital of the nation and its transformation was investigated by I. Rozmainskii (2011). The reproduction of the Russian population, the demographic factors of the human capital were studied by A.G. Vishnevskii et al. (2003). The Russian labor market and the structure of workplaces were investigated by V.E. Gimpel'son, V.N. Rudakov (2015), the regional labor markets - by A.Iu. Oshchepkov and R.I. Kapeliushnikov (2015), labor migration - by E.M. Chernina (2015); informal employment I.B. Voskoboinikov and V.E. Gimpel'son (2015), V.E. Gimpel'son and R.I. Kapeliushnikov (2014), labor mobility - by V.E. Gimpel'son et al (2016); social mobility - by O.I. Shkaratan (2011). The components of the human capital of the Russian Federation and the quality of life are described by V.V. Bushuev et al. (2013). The impact of population education in the Russian regions was studied by A.V. Koritskii (2011). The human and social capital of the youth was studied by a team of scientists of the Institute of Sociology of RAS under the leadership of M.K. Gorshkov and V.V. Petukhov (Gorshkov et al., 2007).

'The capital of perspective' that is a contribution of a motivating vision of the future to the activity of people, productivity of individuals and communities, as well as the return on investments in the creation and support of the vision of the future, is studied very little. In sociology, the vision of the future has been studied as one of the characteristics of various social groups. For example, the vision of the future in the context of values, attitudes to the future, life plans, educational priorities of the youth were investigated by V.N. Shubkin and G.A. Cherednichenko (1994), V.S. Sobkin and P.S. Pisarskii (1994), V.S. Sobkin and N.I. Kuznetsov (1998), D.L. Konstantinovskii (1996), V.M. Slutskii (1995), V.S. Efimov et al. (1999), V.S. Efimov and Iu.V. Chestnov (2001), A.M. Gendin and M.I. Sergeev (1996; 1997), and others.

The processes of 'dissipation' of human resources, which can significantly affect the 'human wealth' of the region and its impact, remain little studied in comparison with the processes of building the human capital. The indicators of 'dissipation' may be the quantity (proportion) of people displaced to the periphery of productive activity including those who are employed in the 
informal economy, low-income social groups, the unemployed, the homeless, without access to social benefits and communications (medicine, education, mobile, the Internet, etc. ).

In addition to the studies of human capital 'in the frame of the present time', namely, its conceptualization, evaluation, measurement, cross-country and inter-regional comparisons, the scientists such as A.A. Taras'ev (2013), A.V. Vasil'eva and A.A. Taras'ev (2014), K.V. Ketova and I.G. Rusiak (2008), V.A. Shabashev and S.I. Shorokhov (2015), A.P. Egorshin et al. (2012), O.A. Kosorukov et al. (2010), S.A. Sukneva (Mikhailova et al., 2014), and others, conducted a series of forward-looking researches. This is mainly the forecasts of the labor market at different levels. Another aspect of the future of human capital is discussed in the works about the definition of 'competencies of the future' and 'foreseeing the future' of vocational education; the works carried out at present by the Agency for Strategic Initiatives (ASI) in the genre of foresight may also be noted.

The foresight study of the future of the human capital of the region (of Krasnoyarsk Krai), conducted by a team of researchers led by V.S. Efimov (Efimov et al., 2010) can be considered a precedent of a more comprehensive study.

\section{Categories as 'assembly structures' for the study of human capital}

As previously indicated, the expansion of the boundaries of ideas about human capital engaged a very wide range of human qualities (at the individual and social levels) and its productivity factors in the subject of research. In order to organize this diversity, it is useful, firstly, to determine the categorical schemes that will make the layout, 'to dilimit and match' different components of the field of research; secondly, to identify the most important focus that is priority topics and issues.
It is possible to use bunches of categories 'material-processes - conditions' and 'subjects - interests / positions - activities' as a categorical grid.

Material ('carriers'), on which the processes of reproduction and development unfold, is man in the broadest sense (individuals, teams, groups). The studies of human capital so far have focused mainly on the 'quality' and potential of individuals, while the capacity of communities and 'human systems' is recognized only in the statistical characteristics of individuals (for example, the percentage of individuals with a certain level of qualification $)^{4}$. However, in economy, culture, politics, etc. the acting force is not individuals, but collectives, groups, teams. It is their potential (not reducible to the sum of qualifications, skills and motivations of individuals within them) that is crucial for the productivity of the society.

Basic processes are human reproduction (at all levels - individuals, collectives, groups, ethnic groups); human development; human capitalization. Processes can be captured through the observed trends, the dynamics of human capital.

\section{Conditions - infrastructures and media} in which the reproduction, development and capitalization of people and groups is possible (e.g., infrastructures and media for business, educational and cultural infrastructures and media, etc.).

Subjects of development and capitalization of man ('capitalists') - groups and instances, which make investments (of different types of resources) in human development and get a return on these investments.

Interests/positions of subjects - in order to understand the perspectives of development of human capital in the country or region, it is important to understand what are the intentions and plans of 'capitalists', what are their abilities to make 'investments in man', within which 
horizons and frames they act now and intend to act in future (and thus define the prospects for human capitalization).

Activity of subjects of human capital development - its subject, content, applied methods and means of activity.

Accordingly, it is possible to define the following focuses of human capital research in the country or region: 1) in terms of the material it is the diversity and characteristics of human capital that exists in different 'carriers'; the population structure in terms of human capital; 2 ) in terms of processes - these are the features of the formation of human capital in a globalized world; processes of human capitalization; 3) in terms of conditions - these are infrastructures and media of the reproduction and development of human capital; 4) in terms of subjects - this is presence and 'capacity' of the subjects of human capital development; 5) from the point of view of interests / positions - this is the content of the goals and interests of different subjects, the degree of their consistency; 6) from the perspective of the activity of subjects - this is applied methods of influence on human capital, the resources used.

\section{The key focus of human capital research}

\section{'Carriers' of human capital}

Human capital can be considered at several levels. They are an individual person, an organization, a country, a people, a nation.

- Individual human capital is characteristics of health, activity, identity, motivation, education and skills, personal experience of an individual person.

- The human capital of the organization is employees with packages of competencies; formed groups and 'teams'. The characteristics of the human capital of the organization is a set of competencies, methods of work and labor skills of the employees; the degree of harmony and efficiency within collectives.

- The human capital of the country, region or city is economically active population, carrying out an economic activity, capable of initiating economic, social and cultural changes (innovation, entrepreneurship, socio-cultural projects). The characteristics of the human capital at this level are the average life expectancy, fertility level, educational level, GDP per capita, the level of business and social activity.

- The human capital of a people (an ethnic group) is the elite and society whose activity allows setting, keeping and solving the problems of long-term well-being of the people in the changing external conditions. The characteristics of the human capital are ethno-cultural identity, the level of activity aimed at the reproduction of people (demographic and ethnocultural).

- The human capital of the nation is the elite and society, whose activity of can meet the challenges of a long-term existence of the nation. The characteristics of the human capital are civil identity, the level of activity, the level of consolidation.

The structure of the population in terms of human capital

Human capital cannot be regarded in a 'naturalistic' manner as the number of people or groups of people with their qualities; it is a 'systemic effect' that depends on conditions of capitalization. For example, the effective organization of production processes in the company dramatically increases the impact of workers despite the fact that persons remain the same and the level of their qualification does not change. Yet, considering the human capital of the region, it is necessary to identify the key groups of population, thereby to obtain 'the focus of attention', particularly, the important thing that is to be investigated, taken into consideration in the first place. The 
most significant things for the prospects of the region are:

- Elite - leaders of politics, business and culture;

- Active part of the population entrepreneurs, innovators in economics, social and cultural spheres;

- Highly qualified segment of the population;

- Moderately qualified segment of the population;

- Low-skilled segment of the population;

- 'Unadapted persons' - superseded to the periphery of social reproduction processes (the unemployed, working in the 'gray zone', the selfemployed with low income).

\section{Human capital in a globalized world}

The current policy of human capital development in the regions and countries is departing from the model of a 'closed society', implying that it is necessary to ensure the reproduction of human capital within the same region or country. An alternative model of 'open society' focuses on the possibility of 'import' and 'export' of human capital; the characteristics of human mobility, communication skills, tolerance are becoming essential.

The regions of Russia in the modern world are open in terms of human capital. It means they are included in the flows of settlement, labor and educational migration. The socio-economic development of the region requires not only the people living in its territory. For example, a spurt of industrialization of the eastern regions of Russia (Siberia and the Far East) in the $20^{\text {th }}$ century was made with the participation of representatives of many nations; the population increased dramatically at the expense of migrants. In the $21^{\text {st }}$ century the movement of these regions to the future may need Moscow engineers, Korean doctors, Chinese builders, Indian IT-specialists, etc. In the world of digital technology and telecommunications, many of them can work online. On the other hand, 'the return of the person' will be linked to the degree to which inter-regional and inter-country cooperation will be built, how these regions will be included in the economic, cultural and educational ties, how well their positioning and image will be built.

\section{Human capitalization process}

Man - individuals or collectives - with the best qualities, a high potential (including competencies, health, activity) are not 'human capital' yet. They become capital when they start to 'work', engage in the activities and bring 'return', 'dividends' of various kinds (economic, status, etc.). Thus, 'capitalization' that is a productive use of human potential, self-realization of man should take place.

The key areas of human self-realization are business and labor, social and cultural activity. Accordingly, the capitalizations requires institutional and infrastructural conditions, a sufficient 'density' of communications and activities, an access to resources of all sorts for work and entrepreneurship, social and cultural activities. The region can be either a medium, which is favorable and 'rich' for human capitalization, for a high return on his activity, initiative, skills, health, or 'a desert' in which human capital, no matter what it would be, 'does not work'.

It is especially important to note such an condition for human self-realization and capitalization, as a mobilizing vision of the future. The positive image of the future of the region mobilizes activity, and people aspire to work, get an education, give birth and raise their children, maintain their health, use all the opportunities in life fully, and 'build themselves'. A negative or unclear image of the future inhibits activity (the most active people leave the region in search of better living and self-actualization conditions). 
We can talk about 'the capital of perspective' that is a reached consensus of different active groups of society with respect to the desired future, which is a condition for the activity, individual 'contributions' of people to the economic and social development of their 'small homeland'.

Infrastructures, institutions and media for human capital development

The processes of human reproduction and development are provided by the appropriate infrastructures and media. Within the industrial phase of the development of society the systems of educational, health and culture institutions are key infrastructures; their activity itself is arranged in an 'industrial' way as a standardized, 'conveying' production of human resources.

In the post-industrial world the processes of human capital reproduction and development become more complex and diversified. The systems of education and health care continue to 'work', however, a crucial role for building human capacity, abilities, competencies and personality traits is played by: 1) free time as a condition for initiatives and pilot activities; 2) communication media (urban medium, virtual communication medium); 3) cognitive technologies, tools, institutions that enhance human intellectual capabilities; 4) humanitarian technologies and institutions, aimed at the initiation and support of human subjectivity and activity (Fig. 1).
New, forming infrastructures, institutions and media are significant, because they create the conditions for a particular human experience - the experience of development as a 'shift of frames' of activities and existence in general, the experience in 'getting' in new contexts, where, in fact, human selfdevelopment is demanded. An important task of the study of human capital is to understand what institutions and infrastructures will be key for the development of human capital in the future.

The subjects of human development and capitalization ('capitalists')

In order to understand the prospects for the development of human capital in the region, it is important to understand who 'capitalists' subjects of human capitalization - are, what their intentions and plans are, as well as their ability to make 'investments in man', in which horizons and frames they act now and intend to act in the future (and thereby define the prospects for human capitalization). The most important subjects interested in human capitalization are:

- People themselves - they are interested in getting a return on their education and skills, efforts aimed at 'fitting' into groups and communities, at achieving a certain social status;

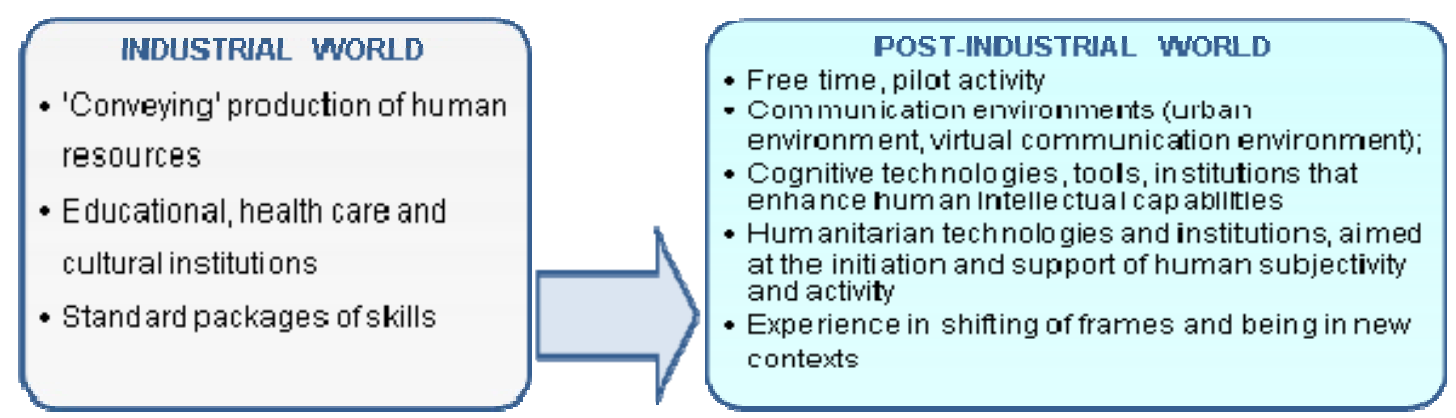

Fig. 1. The conditions of infrastructure and institutions of formation and development of human capital in the industrial and post-industrial world 
- With respect to young people - their parents, they invest in education, health, living conditions, social status of their children;

- Business - it bears the costs of recruiting and selection of personnel, adaptation and retention of employees, ensuring loyalty and work motivation, corporate training, professional development;

- Regional and municipal authorities - they bear the expenses of establishing educational and cultural infrastructures and media, health care, support for the urban medium, creates conditions for economic activities and others.

\section{Interests/subjects positions}

In order to build the human capital of the region, it is important to manifest and coordinate the positions of all the subjects of human capitalization. The study of human capital in the region should include the study of subjects of human capitalization, their interests, attitudes, intentions and available resources.

The specificity of human capital management is determined by the fact that different subjects, carriers of different positions, goals and interests can simultaneously act as 'capitalists' in relation to the same human individuals and groups. Different, often competing, control actions can unfold on the same 'material' (the processes of generation, development and use of human capital). The distribution of applicants by majors in universities can be an example of the competition of control actions. From the point of view of subjects, acting in the framework of providing human resources for the regional economy, we need engineers, technologists, geologists, etc., at the same time, parents sensitize their children (and often finance them) to choose majors in law, economy, management considering these majors a springboard for a career of a chief. Another example of the conflict of control actions may be situations where companies (mining, metallurgy, etc.) hire workers in small cities and towns taking out few remaining young men, and thus crossing out the efforts of municipalities to keep local businesses in a viable state. The conflicts of interests of an individual person and a corporation or a state claiming for his resource are very typical. In today's world the most active and mobile part of people resolve these conflicts by changing work place, region or country of residence.

Human Capital Management requires determining subjects, which are present in the situation (implicitly or explicitly), identifying and aligning their goals and interests. The intensive building of human capital takes place in those areas where there are strong (which have strategies and programs of actions, as well as finance) subjects and where the ideas about the future, the objectives and the interests of various subjects are agreed upon.

\section{Human capital - a systemic view}

As noted earlier, it is necessary to build a systemic picture of human capital, which should integrate:

1) classic notions of human capital and its components: education capital (education and competencies), culture capital, health capital; for countries and regions it is 'demographic capital' (defined by population, its age structure, reproductive and migratory behavior);

2) enhanced representations of human capital, including personality traits of people, their activity, identity (social, ethnocultural, etc.); the availability and characteristics of not only individuals but also collectives, groups and teams, whose potential is not reduced to the sum of the potentials of their constituent individuals;

3) ideas about the media and the institutions that provide building human capital and the possibility of capitalization of accumulated human potential, which are health care and education systems, the media of non-formal education 
Table 1. Directions, characteristics and research methods of human capital

\begin{tabular}{|c|c|c|}
\hline $\begin{array}{l}\text { Directions of human } \\
\text { capital research }\end{array}$ & Characteristics of human capital & $\begin{array}{l}\text { Research methods } \\
\text { (of fixing, evaluation) }\end{array}$ \\
\hline Demographic capital & $\begin{array}{l}\text { Population, age structure, fertility/ } \\
\text { mortality, migration flows rate }\end{array}$ & $\begin{array}{l}\text { Analysis of demographic and migration } \\
\text { statistics }\end{array}$ \\
\hline Health capital & $\begin{array}{l}\text { Population health, morbidity, mortality } \\
\text { rate }\end{array}$ & $\begin{array}{l}\text { Analysis of medical, statistical data, } \\
\text { expert poll }\end{array}$ \\
\hline $\begin{array}{l}\text { Education capital (level of } \\
\text { education, competencies, } \\
\text { experience in activities) }\end{array}$ & $\begin{array}{l}\text { The structure of population in terms of } \\
\text { education level; the number of } \mathrm{PhDs} \\
\text { and Doctors; the number of certified } \\
\text { professionals; the number of certificates } \\
\text { and patents }\end{array}$ & $\begin{array}{l}\text { Analysis of statistics, sociological survey, } \\
\text { expert poll }\end{array}$ \\
\hline $\begin{array}{l}\text { Personal capital } \\
\text { (personality, identity, } \\
\text { activity, mobility) }\end{array}$ & $\begin{array}{l}\text { The structure of population in terms } \\
\text { of significant personal characteristics, } \\
\text { identity, economic and social activity, } \\
\text { mobility and others. }\end{array}$ & Sociological survey, expert poll \\
\hline $\begin{array}{l}\text { Collectivity capital } \\
\text { (collectives, 'teams', their } \\
\text { potential) }\end{array}$ & $\begin{array}{l}\text { Availability of competitive collectives, } \\
\text { groups, teams in the sectors of production, } \\
\text { science, education, culture and others, } \\
\text { which are important for the region }\end{array}$ & $\begin{array}{l}\text { Analysis of data on the productivity of } \\
\text { collectives (manufacturing, scientometric } \\
\text { and other rates, the share of markets). } \\
\text { Analysis of ratings (industrial companies, } \\
\text { universities, research institutions, and } \\
\text { others). Expert poll }\end{array}$ \\
\hline $\begin{array}{l}\text { Social capital (the level of } \\
\text { trust, openness, tolerance, } \\
\text { solidarity, etc.). }\end{array}$ & $\begin{array}{l}\text { The number of public organizations } \\
\text { and associations, public involvement in } \\
\text { community activities, volunteer activity. } \\
\text { The level of trust, openness, tolerance, and } \\
\text { solidarity. The level of anti-social, criminal } \\
\text { behavior, mortality rates for social reasons }\end{array}$ & $\begin{array}{l}\text { Analysis of statistics, sociological survey, } \\
\text { expert poll }\end{array}$ \\
\hline $\begin{array}{l}\text { Degradation of human } \\
\text { capital }\end{array}$ & $\begin{array}{l}\text { The share of the population employed in } \\
\text { the informal economy; unemployment } \\
\text { rate, 'stagnant' poverty rate; proportion } \\
\text { of the population in a state of social and } \\
\text { communicative deprivation; marginalized } \\
\text { groups (repeatedly convicted individuals, } \\
\text { marginalized representatives of social and } \\
\text { ethnic minorities) }\end{array}$ & $\begin{array}{l}\text { Analysis of statistics Sociological } \\
\text { survey } \\
\text { Expert poll }\end{array}$ \\
\hline $\begin{array}{l}\text { Terms of human } \\
\text { capitalization }\end{array}$ & $\begin{array}{l}\text { The structure of the labormarket, the quality } \\
\text { of the business medium, entrepreneurship } \\
\text { support system (including protection } \\
\text { against corruption and red tape), and } \\
\text { others. The degree of public acceptance } \\
\text { of economic and social activity, the level } \\
\text { of innovation resistance. The level of } \\
\text { development of the urban medium }\end{array}$ & $\begin{array}{l}\text { Analysis of statistics } \\
\text { Expert poll }\end{array}$ \\
\hline
\end{tabular}


Table 1. Directions, characteristics and research methods of human capital

\begin{tabular}{|l|l|l|}
\hline $\begin{array}{c}\text { Directions of human } \\
\text { capital research }\end{array}$ & \multicolumn{1}{|c|}{ Characteristics of human capital } & \multicolumn{1}{|c|}{$\begin{array}{c}\text { Research methods } \\
\text { (of fixing, evaluation) }\end{array}$} \\
\hline $\begin{array}{l}\text { Perspective capital } \\
\text { (focusing on the future, } \\
\text { solidarity with the elite, } \\
\text { optimism) }\end{array}$ & $\begin{array}{l}\text { The structure of population from the } \\
\text { perspective of development of the } \\
\text { country, region, city; solidarity with the } \\
\text { elite (approval/disapproval, agreement/ } \\
\text { disagreement, etc.). Focusing on the future, } \\
\text { optimism about their plans, belief in career } \\
\text { and personal growth, opportunities to } \\
\text { improve the level and quality of life }\end{array}$ & \\
\hline
\end{tabular}

and accumulation of personal experience (urban media, etc.); labor market;

4) ideas about social capital that is a quality of a society determining the possibility of human activity and productivity (the level of trust in society and the development of conditions for social activity, the level of risk);

5) ideas about the subjects interested in investing in human capital and human capitalization;

6) ideas about negative processes, leading to 'dissipation' of human resources (pushing out a part of population to the informal economy, chronic poverty, the state of social and communicative deprivation).

The issue of 'operationality' of different components of the required systemic ideas about human capital is important. These components must be available for empirical fixing, qualitative and quantitative evaluation. Table 1 shows a sketch of empirically available characteristics of different components of the system model of human capital and research methods of these characteristics.

\section{Conclusions}

To date, many studies of the human capital have retained the reduction of human capital to its individual components, as well as to the characteristics of individuals. This approach leads to the problems and paradoxes of human capital measurement, estimation of its accumulation, measurement of its economic impact: significant correlation between economic growth and human capital are not found either in time or in crosscountry context; human capital, as the stock of public education accumulated by the population, can slightly influence the economic performance in the case of high unemployment, an inefficient use of labor. The relationship between investments in human capital and the results obtained remains non-obvious. There are significant differences between the estimates of human capital obtained in the framework of different approaches, as well as within the same approach, but with different research techniques.

It is necessary to develop a systemic understanding of the human capital, which takes into account its various aspects and components and the social and collective nature of human activity and productivity, including conditions of human capitalization in the subject of the study. It must integrate 1) classic notions of human capital and its components (education and competencies, health, etc.), 2) enhanced ideas about human capital, including personality, activity, identity of people; features of not only individuals but also collectives and groups; 3) ideas about the media and the institutions that provide the building of human capital and the possibility of 
capitalization of accumulated human potential; 4) ideas about social capital; 5) ideas about the subjects interested in investing in human capital and human capitalization; 6) ideas of negative processes, leading to 'dissipation' of human resources (pushing out the population to the informal economy, chronic poverty, the state of social and communicative deprivation).

The components of the systemic idea about human capital should be operational, in other words, they should be available for empirical fixing, qualitative and quantitative evaluation. A complex of research methods and evaluation of human capital is required, in particular, there is a need for attracting sociological research methods and expert polls to study those aspects that remain outside the statistics.

In order to organize heterogeneous material that is included in the subject of research in the construction of the systemic, an interdisciplinary idea about human capital, you need a 'grid' of categories. As such, the two groups of categories can be used. They are 'material - processes -conditions' and 'subjects - interests / positions activity'.

In order to understand the dynamics of human capital in today's world we need new 'focuses' of the study of human capital. Thus, among the 'carriers' of human capital the elite and young people are of particular interest they can be considered 'agents of the future', the capacity and the activity of which influence primarily the socio-economic development of the country, region, city. An important focus is the study of the processes of formation or dissipation of human capital in the context of globalization, where countries and regions are 'open' and compete for human capital, while the 'return of the person' is associated with the extent to which an inter-regional, inter-country cooperation is built.

It is necessary to study the institutional and infrastructural conditions of human capitalization, because the latter requires the 'density' of communications and activities; the access to the resources necessary for work and entrepreneurship, for social and cultural activities; the presence of a motivating vision of the future (the capital of perspective). Examining infrastructures and institutions needed for human development, we should be aware that in the postindustrial world the things, which are not less important than the systems of educational, health care and culture institutions, are: free time, communication media; cognitive technologies and institutions that enhance human intellectual capabilities; humanitarian technologies and institutions, aimed at the initiation and support of subjectivity and human activity. The subjects of human development and capitalization, their interests and positions, as well as their activity, which are the ways of influencing human capital, applied technologies and resources, are becoming an important component of the research object.

The detailed overview works, including the analysis and criticism of the different concepts of human capital, the measurement and evaluation methods of human capital, are represented by V.N. Cherkovets (2009), I.V. Soboleva (2009), R.I. Kapeliushnikov $(2008,2012)$.

2 The analysis of the position of A. Smith in the context of the formation of prerequisites for the human capital theory was conducted by V.N. Cherkovets (2009, 90-92). It is shown that A. Smith raised the question of the value and payback for the training; determining the structure of fixed capital; along with cars, different buildings, improved land, he mentioned "acquired and useful abilities of all the inhabitants or members of the public." At the same time A. Smith clearly opposed labor and capital as the factors of production and could not (in the conceptual framework which he specified) consider skills and knowledge of workers as a capital, which is able to generate revenue for the owner in addition to his work efforts.

In the Russian science the ideas of Bourdieu are developed by V.V. Radaev (2002).

4 Apparently, the fact that the concept of human capital was developed initially as part of the economic theories that were based on the principle of 'methodological individualism' played a role, i.e., the economic reality was understood as composed of its atoms - individuals, acting independently and making decisions based on one's own interests. 


\section{References}

Aivazian, S.A. (2003a). K metodologii izmereniia sinteticheskikh kategorii kachestva zhizni naseleniia [On the methodology of measuring synthetic categories of the quality of population life], In Ekonomika i matematicheskie metody [Economics and Mathematical Methods], 39 (2), $33-53$.

Aivazian, S.A. (2003b). An empirical analysis of the synthetic categories of the quality of population's life, In Ekonomika i matematicheskie metody [Economics and Mathematical Methods], 39 (3), 19-53.

Belkin, V.N., Belkina, N.A., Garina, V.Iu, Vladykina, L.B., Antonova, O.A., Gorbunov, V.D., Luzin, N.A., \& Kuzmenko A.V. (2012). Teoriia chelovecheskogo kapitala predpriiatiia [The theory of the human capital of the enterprise]. Yekaterinburg, Russian Academy of Sciences, Ural Branch, Institute of Economics, 398.

Bourdieu, P. (2001). Forms of Capital, In The Sociology of Economic Life. Granovetter, M. and Swedberg, R. (eds.). 2nd ed. Boulder, Westview Press, 96-111.

Bovenberg, A.L. (2008).The Life-course perspective and social policies: An overview of the issues, In CESifo Economic Studies, 54 (4), 593-641.

Bowen, H.R. (1978). Investment in Learning. San Francisco etc: Jossey-Bass, 362.

Bushuev, V.V., Golubev, V.S., Kos'ianenko, A.V. \& Tarko, A.M. (2013). Vosproizvodimyi kapital i kachestvo zhizni - 2009: mir i sub"ekty Rossiiskoi Federatsii [Playable capital and quality of life 2009: the world and subjects of the Russian Federation], In Uroven' zhizni naseleniia regionov Rossii [The living standard of the population of Russian regions], 4, 63-125.

Cherkovets, V.N. (2009). Kategoriia «chelovecheskii kapital» v obshchei ekonomicheskoi teorii: istoricheskii vzglyad i soderzhatel'noe opredelenie [The category of 'human capital' in general economic theory: historical point of view and content definition], In Rossiiskii ekonomichekii zhurnal [Russian Economic Journal], 7-8, 88-107.

Chernina, E.M. (2015). Vybor napravleniia migratsii: rol' proshlogo opyta [The choice of the direction of migration: the role of past experience]. Moscow, Higher School of Economics Publishing House, 27.

Dobrynin, A.N., Diatlov, S.A., \& Tsyrenova, D.E. (1999a). Chelovecheskii kapital v tranzitivnoi ekonomike: formirovanie, otsenka, effektivnost' ispol'zovaniia [Human capital in transitive economy: formation, evaluation, efficiency]. St. Petersburg, Nauka, 309.

Dobrynin, A.I., Diatlov, S.A., \& Kurpanskii, S.A. (1999b). Metodologiia otsenki chelovecheskogo kapitala [Methodology for evaluation of human capital], In Ekonomika obrazovaniia [Economics of Education], 1, 9-25.

Efimov, V.S., Efimova, L.I., \& Chestnov, Iu.V. (1999). Shkol'noe obrazovanie v Rossii: psikhologicheskie i social'no-ekonomicheskie aspekty [School education in Russia: psychological and socio-economic aspects], In Obrazovanie i sotsial'noe razvitie regiona [Education and social development of the region], 1-2, 144-156.

Efimov, V.S., Koptseva, N.P., Mazharov, V.F., Shishatskii, N.G., Briukhanova, E.A., Butenko, A.V., Gornyi, B.E., Ivanova, L.V., \& Lapteva, A.V. (2010). Chelovecheskii kapital Krasnoiarskogo kraia: forsait-issledovanie - 2030. Analiticheskii doklad [Human capital of Krasnoyarsk Krai: Foresight Study - 2030. Analytical report]. Krasnoyarsk, 126. 
Efimov, V.S., Lapteva, A.V., Efimov, A.V. \& Vcherashnii, P.M. (2015). Politika narashchivaniia chelovecheskogo kapitala Sibiri i Dal'nego Vostoka [The policy of building the human capital of Siberia and the Far East], In EKO: Vserossiiskii ekonomicheskii zhurnal [ECO: Russian Economic Journal], 2 (488), 28-38.

Efimov, V.S., \& Chestnov, Iu.V. (2001). Starsheklassniki Krasnoiarska na poroge XXI veka: sociologicheskii portret [High school students in Krasnoyarsk on the threshold of the 21st century: sociological portrait]. Krasnoyarsk, Krasnoyarsk State University, 187.

Egorshin, A.P., Gus'kova, I.V. \& Ponomareva, O.G. (2012). Razrabotka stsenariev, prognoz rynkov truda $i$ vysshego obrazovaniia [Development of scenarios, forecast of labor and higher education markets]. Higher Education Today, 1, 24-28.

Gendin, A.M., \& Sergeev, M.I. (1996). Regional'nye osobennosti tsennostnykh orientatsii uchashchikhsia, roditelei i uchitelei [Regional features of valuable orientations of students, parents and teachers], In Obrazovanie v Sibiri [Education in Siberia], 1, 64-69.

Gendin, A.M., \& Sergeev, M.I.(1997). Motivy i faktory professional'nogo vybora starsheklassnikov (po materialam sotsiologicheskogo issledovaniia) [Motives and factors of professional choice of high school students (based on sociological research)], In Obrazovanie v Sibiri [Education in Siberia], 1, $5-12$.

Gimpel'son, V.E. \& Kapeliushnikov, R.I. (ed.) (2014). V teni regulirovaniia: neformal'nost' na rossiiskom rynke truda [In the shadow of regulation: informality of the Russian labor market]. Moscow, Higher School of Economics Publishing House, 535.

Gimpel'son, V.E., Kapeliushnikov, R.I., \& Sharunina, A.V. (2016). «Dorogi, kotorye my vybiraem»: peremeshcheniia na vneshnem i vnutrennem rynke truda ["The roads that we choose": moving along the internal and external labor markets]. Moscow, Higher School of Economics Publishing House, 48.

Gorshkov, M.K., Petukhov, V.V. Andreev, A.L., Anikin, V.A. Goriunova, S.V., Davydova, N.M., Zadorin, I.V., Lezhnina, Iu.P., Ovchinnikova, Iu.V., Pakhomova, E.I., Sedova, N.N., Tikhonova, N.E., \& Khromov, K.A. (2007). Molodezh' novoi Rossii: obraz zhizni i tsennostnye prioritety [Young people of the new Russia: lifestyle and value priorities]. Moscow, Russian Academy of Sciences, Institute of Sociology, 95.

Handel, M. J. (2003). Skills mismatch in the labor market, In Annual Review of Sociology, 29, 135-165.

Ilyinsky, IV (1996). Investitsii v budushchee: obrazovanie v innovatsionnom proizvodstve [Investing in the future: education in innovative production]. SPb, SPbUEF, 163.

Ivanov, Iu.N., \& Sagradov, A.A. (2001). K voprosu ob ischislenii i analize pokazatelei chelovecheskogo razvitiia $\mathrm{v}$ regionakh Rossii [On the question of the calculation and analysis of the human development rate in the regions of Russia], In Voprosy statistiki [Statistical Studies], 2, 23-26.

Kapeliushnikov, R.I. (2008). Zapiska ob otechestvennom chelovecheskom kapitale [Note on the domestic human capital]. Moscow, HSE Publishing House, 56.

Kapeliushnikov, R.I. (2012). Skol'ko stoit chelovecheskii kapital Rossii? [How much does human capital Russia?] Moscow, HSE Publishing House, 76.

Ketova, K.V., \& Rusiak, I.G. (2008). Uchet chelovecheskogo kapitala pri modelirovanii ehkonomicheskoj sistemy regiona [Accounting for human capital in the modeling of the economic 
system in the region], In Vestnik Moskovskogo universiteta. Ekonomika [Bulletin of Moscow University. Economics], 6 (3), 40-51.

Konstantinovskii,D.L.(1996).Dinamikaprivlekatel'nostiprofessii,Professional'noesamoopredelenie vypusknikov obshcheobrazovatel'nykh shkol. Po materialam massovykh sociologicheskikh obsledovanii molodezhi. Sb. nauchn. trudov [Dynamics of occupations' attractiveness. Professional self-determination of secondary school graduates. According to the materials of mass sociological surveys of youth. Collection of scientific works]. Moscow, TSSO RAO, 12-49.

Koritskii, A.V. (2011). Komu prinosyat vygody raskhody na obrazovanie v Rossii? [Who gets the benefits from spending on education in Russia?], In Voprosy innovatsionnoi ekonomiki [Innovative Economy Issues], 7, 27-41.

Kosorukov, O.A., Petrikova, E.M., \& Petrikova, S.M. (2010). Makroekonomicheskie metody prognozirovaniia rynka truda $\mathrm{v}$ regional'noi ekonomike [Macroeconomic forecasting methods of the labor market in the regional economy], In Regional'naia ekonomika: teoriia i praktika [Regional economy: theory and practice], 45, 10-25.

Koulman, J. (2001). Kapital sotsial'nyi i chelovecheskii [Social and human capital], In Obshchestvennye nauki i sovremennost' [Social Sciences and modernity], 3, 121-139.

Machlup, F. (1984). The Economics of Information and Human Capital. Princeton, 419.

Mikhailova, E.I., Efimov V.S, Borisova, U.S., Lapteva, A.V., Naberezhnaia, A.T., Savvina, N.V., Savvinov, V.M., Sukneva, S.A., Fedorov, M.P., \& Iakovleva, K.M. (2014). Respublika Sakha (Yakutiia) - 2050. Forsait-issledovanie [The Republic of Sakha (Yakutia) - 2050. Foresight study]. Yakutsk, North-Eastern Federal University Publishing House, 184.

Mil'ner, B. (2008). Nematerial'nye aktivy kompanii [Intangible assets of the company], In Problemy teorii i praktiki upravleniia [Problems of the theory and practice of management], 3, 109-118.

Oshchepkov, A.Iu., \& Kapeliushnikov, R.I. (2015). Regional'nye rynki truda: 15 let razlichii [Regional labor markets: 15 years of difference]. Higher School of Economics Publishing House, 73.

Radaev, V.V.aa (2002). Poniatie kapitala, formy kapitalov i ikh konvertatsiia [The concept of capital, forms of capital and their conversion], In Ekonomicheskaia sotsiologiia [Economic Sociology], 3 (4), 20-32.

Rozmainsky, I. (2011). Pochemu kapital zdorov'ia nakaplivaetsia v razvitykh stranakh i «proedaetsia» v postsovetskoi Rossii? (Opyt postkeinsianskogo analiza) [Why is health capital accumulated in developed countries and 'eaten away' in post-Soviet Russia? (The experience of postKeynesian analysis), In Voprosy ekonomiki [Economy Issues], 10, 113-131.

Rudakov, V.N. (2015). Ekonomicheskoe polozhenie molodezhi na rossiiskom rynke truda $v$ terminkah zarabotnoi platy [The economic situation of young people in the Russian labor market in terms of wages]. Moscow, Higher School of Economics Publishing House, 27.

Schultz, T.W. (1981). Investing in people. The Economics of population Quality. Berkeley, University of California Press, 173.

Schultz, T.W. (1971). Investment in human capital: the role of education and of research. N.Y., Free Press.

Shabashev, V.A., \& Shorokhov, S.I. (2015). Vliianie chelovecheskogo kapitala na ekonomicheskii rost v regionakhs razlichnoi proizvodstvennoi strukturoi [The impact of human capital on the economic growth in regions with different industrial structure]. Kemerovo, AI 'Kuzbassvuzizdat', 2003. 
Shkaratan, O.I. (2011). Ozhidaniia i real'nost'. Sotsial'naia mobil'nost' v kontekste problemy ravenstva shansov [Expectations and reality. Social mobility in the context of the problem of equality chances], In Obshchestvennye nauki i sovremennost' [Social Sciences and Modernity], 1, 5-24.

Shubkin, V., \& Cherednichenko, GA (1994). Tsennostnye orientatsii v strukture professional'nogo samoopredeleniia starsheklassnikov. Tipovaya metodika provedeniia sotsiologicheskogo issledovaniia tsennostnykh orientatsii starsheklassnikov v oblasti proforientatsii [Value orientatiosn in the structure of vocational self-determination of senior pupils. A typical method of sociological research of senior pupils' valuable orientations in the field of career counseling]. Moscow, Center for Sociology of Education of Rae, 59.

Slutskii, V.M. (1995). Sotsial'nye izmeneniia i zhiznennye plany detei [Social change and life plans of children], In Tsennostno-normativnye orientatsii starsheklassnika. Trudy po sotsiologii obrazovaniia [Value-normative orientations of the senior. Works on the sociology of education], 3 (4). Moscow, Center for Sociology of Education of RAE, 133-146.

Sobkin, V.S., \& Pisarskii, PS (1994). Zhiznennye tsennosti $i$ otnoshenie $k$ obrazovaniiu: krosskul'turnyi analiz Moskva - Amsterdam. Po materialam sotsiologicheskogo oprosa uchitelei, uchashchikhsia i roditelei [Life values and attitude to education: cross-cultural analysis of Moscow and Amsterdam. According to the materials of a sociological survey of teachers, students and parents]. Moscow, Center of Sociology of RAE, 152.

Sobkin, V.S., \& Kuznetsova, N.I. (1998). Rossiiskii podrostok 90-kh: dvizhenie v zonu riska. Analiticheskii doklad [Russian teenager of the 90-ies: moving to the risk zone. Analytical report]. Moscow, 119.

Soboleva, I.V. (2009). Paradoksy izmereniia chelovecheskogo kapitala. Nauchnyi doklad [Paradoxes of measuring human capital. Scientific report]. Moscow, Institute of Economics, Russian Academy of Sciences, 50.

Taras'ev, A.A. (2013). Postroenie prognoza migratsionnykh potokov v regiony Rossii [The construction of the forecast of migration flows to the regions of Russia], In Ekonomika regiona [Regional Economy], 2 (34), 192-199.

Valentei, S., \& Nesterov, L. (1999). Chelovecheskii potentsial: novye izmeriteli i novye orientiry [Human potential: new meters and new guidelines], In Voprosy Ekonomiki [Economics Issues], 2, 90-102.

Vasil'eva, A.V. \& Taras'ev A.A. (2014). Prognoz razvitiia migratsionnykh protsessov i rynka truda $\mathrm{v}$ regionakh Rossii [The forecast of development of migration processes and the labor market in the regions of Russia], In Ekonomika regiona [Regional Economy], 4 (40), 283-298.

Vishnevskii, A.G., Andreev, E.M., \& Treivish, A.I. (2003). Perspektivy razvitiia Rossii: rol' demograficheskogo faktora [Prospects for Russia's development: the role of the demographic factor]. Moscow, E.T. Gaidar Institute for Economic Policy Foundation, 61.

Voskoboinikov, I.B., Gimpel'son, V.E. (2015). Rost proizvoditel'nosti truda, strukturnye sdvigi i neformal'naia zaniatost' $v$ rossiiskoi ehkonomike [Productivity growth, structural changes and informal employment in the Russian economy]. Moscow, Higher School of Economics Publishing House, 47.

Zubarevich, N.V. (2016). Sotsial'noe razvitie regionov Rossii. Problemy i tendentsii perekhodnogo perioda [Social development of Russian regions. Challenges and tendencies of transition]. Moscow, Lenand, 264. 


\title{
Концепт человеческого капитала - необходимость междисциплинарного \\ синтеза
}

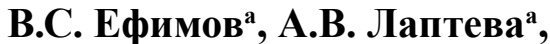 \\ Е.И. Михайлова ${ }^{\sigma}$ \\ ${ }^{a}$ Сибирский федеральный университет \\ Россия, 660041, Красноярск, пр. Свободныий, 79 \\ ${ }^{6}$ Северо-Восточный федеральный университет \\ Россия, 677027, Якутск, ул. Белинского, 58
}

Проведен обзор теоретических и эмпирических исследований человеческого капитала, показавиий недостаточность редуиированных представлений о человеке, его активности и возможности ее реализаџии.

На основании выполненного критического анализа обоснована необходимость разработки системной модели человеческого капитала, которая должна объединить классические представления о человеческом капитале и его компонентах (образованность и компетенции, здоровье, демографический потенциал) с расширенными представлениями, включающими: личностные качества человека, активность, идентичность; характеристики не только индивидов, но и коллективов, групп; понятие «сочиального капитала»; представления об условиях, средах и институтах, которые обеспечивают развитие и капитализацию человека; представления о субъектах капитализации человека; представления о негативных процессах, ведущцих к «диссипациии человеческих ресурсов.

На основании философско-методологического анализа предложены две группы категорий: «материал - прочессы - условия», «субъекты - интересы/позиции - активности», позволяющчие осуществить системную сборку представлений о человеческом капитале.

В отношении прикладных эмпирических исследований обсуждаются: важнейшие фокусировки исследований человеческого капитала; значимые компоненты (характеристики) человеческого капитала; методы исследований (фиксачии, оценки) важнейших характеристик человеческого капитала.

Ключевые слова: человеческий капитал, системное представление, система категорий, методы исследования.

Научная специильность: 08.00.00 - экономические науки. 